\title{
The Removal of Stems from Cut Tobacco
}

D. Zielke and R. Liebe

Hauni Maschinenbau $A G$

Kampchaussee 8.32

D-21033 Hamburg

\section{SUMMARY}

The presence of stems in cut tobacco is detrimental to cigarette quality, resulting in problems during production particularly on today's high-speed makers. Incomplete threshing. and the use of unthreshed semioriental tobaccos can increase the stem content in the cut tobacco considerably. The percentage of stems present in cut tobacco was investigated by Hauni Maschinenbau AG specifically for semi-oriental tobacco. Their findings show that not all stems present in the strips or lamina after cutting are classified as "objectionable". However, the percentage of objectionable stems in the cut tobacco is not inconsiderable and depends on the thickness of the stems present. Reducing the objectionable stem contingent in cut tobacco is therefore a crucial concern of many cigarette manufacturers who set great store on ensuring high-quality product. Hauni Maschinenbau AG offers a cut tobacco separator which has been specially designed for this purpose and also used as a cooler. A corresponding model is available in the Hauni Maschinenbau AG pilot plant in Hamburg for tests using the customers' own tobacco.

Received: 17th April 1997 - accepted: 28th August 1997

\section{ZUSAMMENFASSUNG}

Rippenstücke im Schnittabak haben einen negativen Einfluß auf die Qualität von Zigaretten und führen, besonders bei den heutzutage vorhandenen schnellaufenden Maschinen, zu Problemen bei der Produktion. Unvollständige Entrippung und der Einsatz von sogenannten Semi-Orient Tabaken, die unentrippt verarbeitet werden, erhöhen den Rippenanfall im Schnittabak erheblich.

Die Hauni Maschinenbau AG hat an Semi-Orient Tabak den Rippenanteil im Schnittabak untersucht. Hiernach wird der in den Strips oder Blättern vorhandene Rippenteil nach dem Schneiden nicht vollständig als sogenannte "objectionable stems" im Schnittabak wiedergefunden. Der im Schnittabak vorhandene Anteil ist jedoch nicht unerheblich und abhängig von der Dicke der vorhandenen Rippenteile.

Die Reduzierung der "objectionable stems" im Schnitttabak ist deshalb für viele Zigarettenproduzenten, die Wert auf eine hohe Qualität ihrer Produkte legen, unerläßlich. Die Hauni Maschinenbau AG bietet diesbezüglich einen speziell für diesen Zweck entwickelten Schnittabaksichter, der nebenbei als Xühler Verwendung findet, an. Für Versuche mit eigenen Tabaken steht den Kunden der Hauni Maschinenbau AG ein solcher Sichter in der Hamburger Pilotanlage zur Verfügung. 


\section{RESUME}

La présence de bûches dans le scaferlati a une incidence néfaste sur la qualité des cigarettes et crée, surtout aujourd'hui avec les machines particulièrement rapides, des problèmes au niveau de la production. Une séparation incomplète des côtes et l'exploitation de tabacs de type semi-oriental traités sans écotage préalable accroissent considérablement la présence de bûches dans le scaferlati.

La Société Hauni Maschinenbau AG a analysé la proportion des côtes dans le scaferlati de tabacs semi-orientaux. Il en ressort que la proportion de côtes présente dans les strips ou les feuilles ne réapparaît pas intégralement, après le traitement du tabac dans le hachoir, sous forme de "bûches gênantes" dans le scaferlati. Elle n'est toutefois pas négligeable et dépend de l'épaisseur des brins de côtes présents.

La réduction des "bûches gênantes" dans le scaferlati est, en conséquence, indispensable pour de nombreux producteurs de cigarettes qui attachent une grande valeur à la qualité de leurs produits. Hauni Maschinenbau AG propose, à cet effet, un séparateur de côtes spécialement conçu pour le traitement du scaferlati et faisant office accessoirement de refroidisseur. Un tel séparateur est mis à la disposition des clients de Hauni Maschinenbau AG, dans l'installation pilote hambourgeoise, afin qu'ils puissent y faire des essais avec leur propre tabac.

\section{INTRODUCTION}

The presence of stems in cut tobacco can cause problems in cigarette manufacturing. Particularly on today's highspeed makers stems can be the cause for rod breaks, resulting in downtimes and loss of production. Stems contained in cigarettes can cause stem holes and can be detrimental to the burning characteristics of the cigarette. Fluctuations in pressure drop and fire-ball drop-off can be caused by stems.

The presence of stems in cut tobacco is explained by the fact that stems are left in the tobacco after threshing (up to $3 \%$ stems remain in the strips after threshing) and the use of unthreshed oriental tobaccos. Ttaditionally oriental tobaccos are not threshed (stem content approximately $15 \%$ ). More recently these plants have been bred for larger leaves with thicker stems. Particular attention should be paid to the East European / Asian semi-oriental tobaccos (stem content approximately $24 \%$ ).

Cut tobacco for a normal American blend can have a stem content of $3-4 \%$, depending on the amount of oriental tobacco contained in the blend. Not all stems are classified as "objectionable", or critical stems during cutting as not all stem particles have the full cutting width. The actual percentage of stems present in cut tobacco was investigated by Hauni Maschinenbau AG specifically for semi-oriental tobacco.

Generally the percentage of stems contained in strips or in cut tobacco is determined using the stem tester. The tobacco is repeatedly pounded into small particles, and the stems removed by a separator. This process also pounds some stems into small particles. For this reason the measured results show less stems than actually present. In our investigations we reduced damage to the stems by not using heavy mechanical stress. Cut tobacco was dried to approximately $2 \%$ moisture content to make it very brittle so that it reduced to dust with very little pressure. The hand stems could then be removed by sieving. It was demonstrated that size fraction $>2 \mathrm{~mm}$ contained only stems. Smaller particles consisted of dust and very small non-critical stem particles which do not have a negative effect if contained in the cigarette. Using this method we ascertained a stem content of approx. $14 \%$ in semi-oriental tobacco with a cut width of $0.8 \mathrm{~mm}$. This percentage was surprisingly low as an analysis of semi-oriental leaves (careful manual removal of stems and determination of the stem content) demonstrated a stem content of approx. $24 \%$. This discrepancy formed the basis of the following theoretical considerations:

Each stem which is cut by the cutter generates sections which are narrower than the cutting width. The thinness of these stem particles means that they do not behave in the same way as stems in the cut tobacco. The same applies to stem end pieces which are cut into pieces smaller than the cutting width. Each stem generates particles which are thinner than the cut width and which thus do not adversely affect quality (non-critical thickness).

The proportion of thin particles is defined by the ratio of twice the non-critical thickness to the stem thickness, based on the simplified assumption that all stems are cut lengthways:

$$
A=\frac{2 \cdot s^{*}}{D} \cdot 100
$$

\section{Where}

A = Percentage of non-critical stems (\%)

D = Stem thickness (mm)

$s^{*}=$ Non-critical cut width (mm)

The proportion of stems which become non-critical through cutting is thus dependent on stem thickness and is higher for thinner stems.

Figure 1 shows the calculated percentages (those cut to under $50 \%$ of the cutting width) relative to stem thickness and cutting width. 


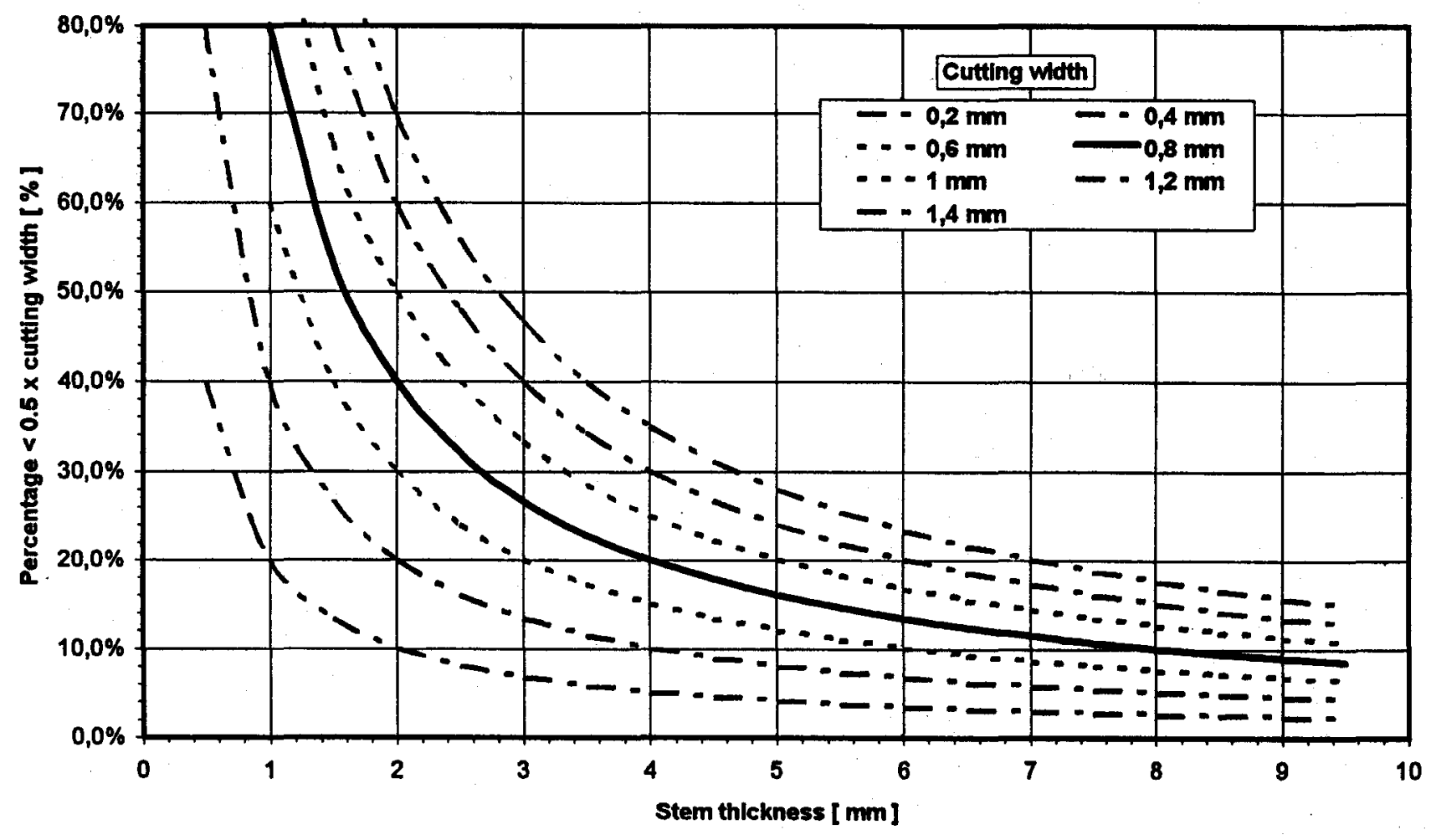

Figure 1.

Percentage of stem particles cut thinner than $0.5 \times$ cutting width relative to stem thickness and cutting width.

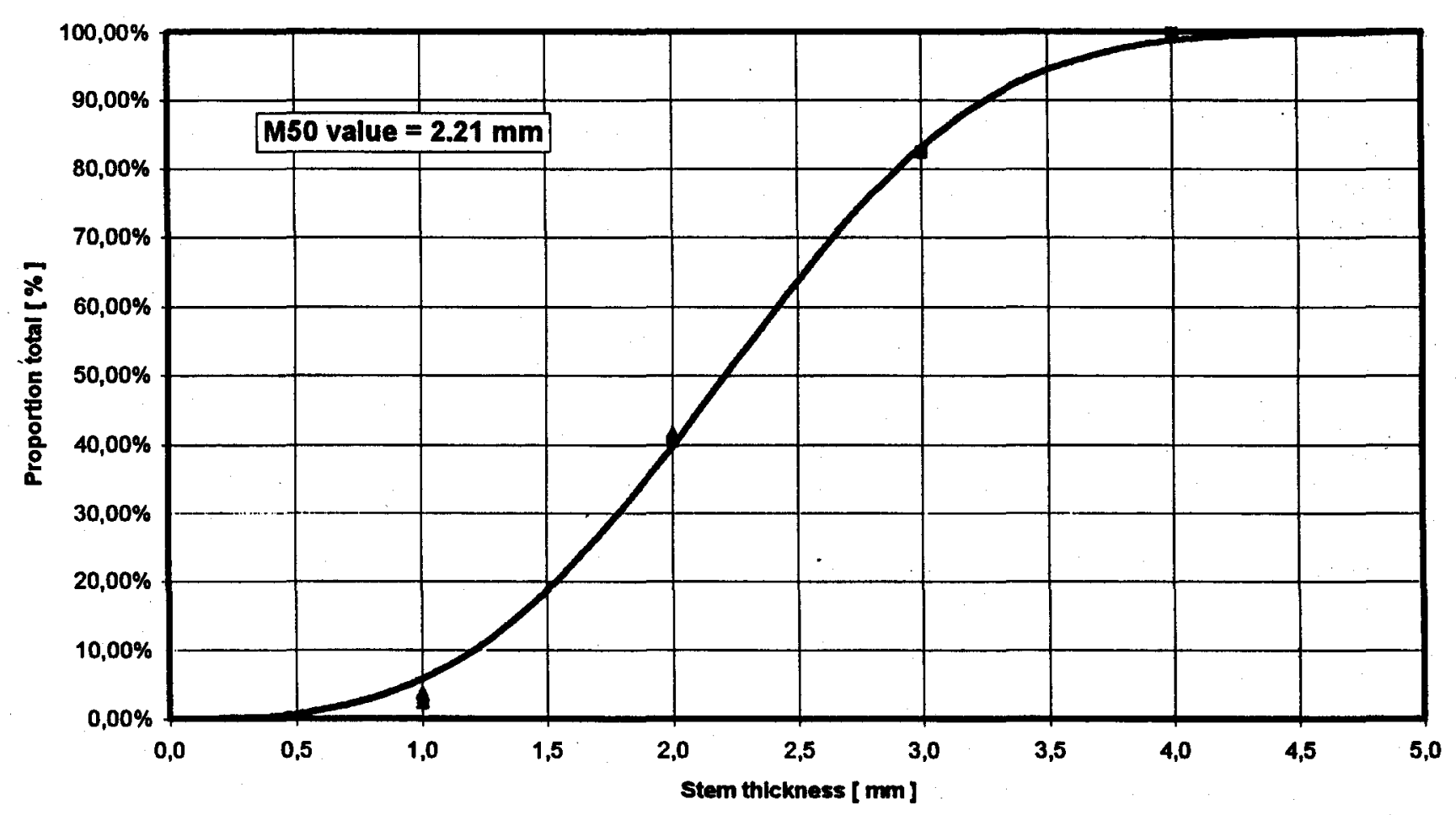

Figure 2.

Distribution of stem thickness in seml-oriental tobacco. 


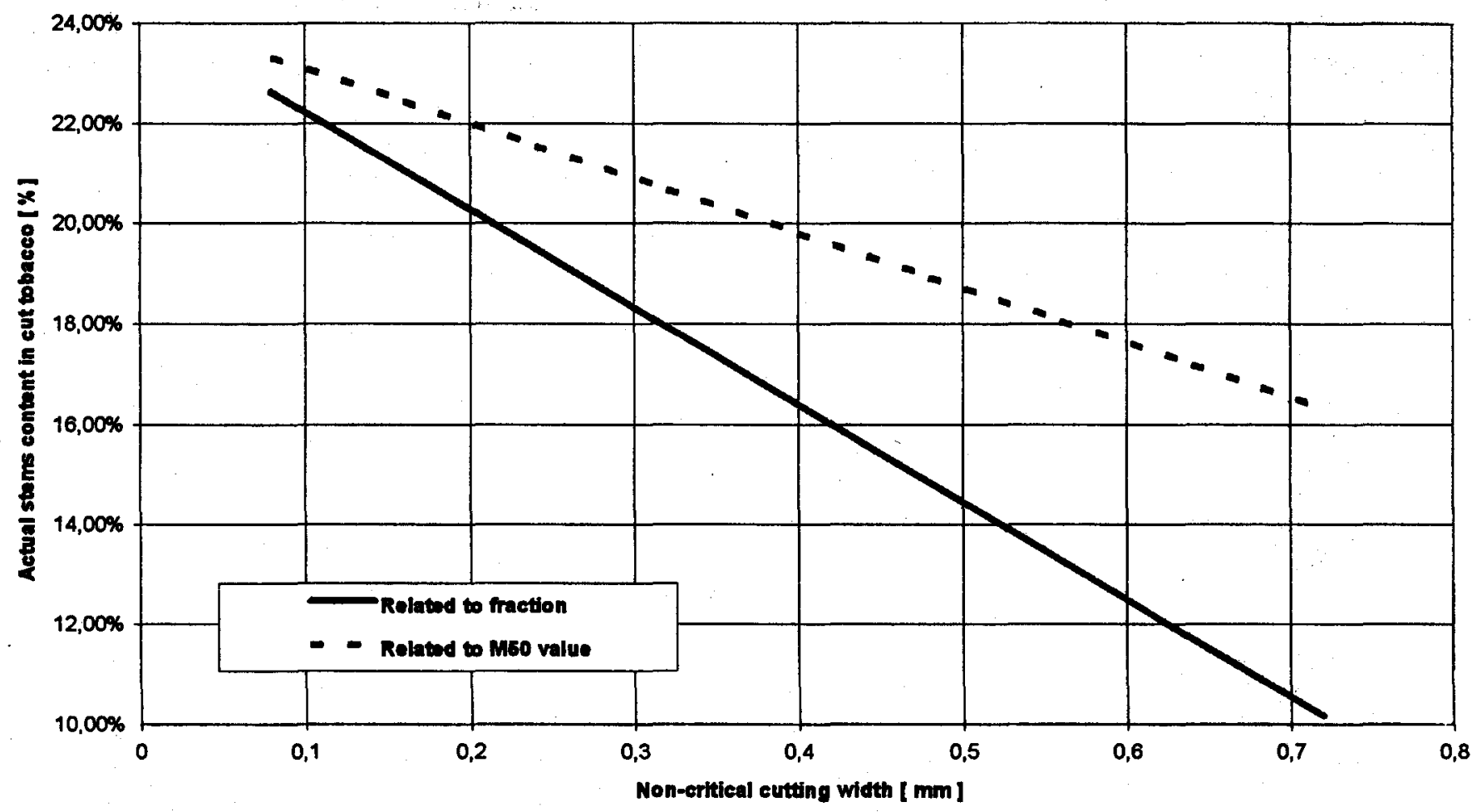

Figure 3.

Percentage of critical stems in cut tobacco with a cutting width of $0.8 \mathrm{~mm}$. Original stem content: $24.18 \%$.

Thus the actual percentage of stems contained in cut tobacco would seem to be reduced considerably by the presence of thin stems. As each leaf always contains both thick and thin stems, knowledge of stem thickness distribution is required for calculation of the percentage of stems contained in cut tobacco. The stem thickness distribution was determined on the basis of the manually removed stems. The stems were dried and broken into

sections approx. $25 \mathrm{~mm}$ in length and classified according to thickness $(0-1 \mathrm{~mm}, 1-2 \mathrm{~mm}, 2-3 \mathrm{~mm}, 3-4 \mathrm{~mm}$, $4-5 \mathrm{~mm},>5 \mathrm{~mm})$. The weights of the groups reflected the distribution of stem thickness, as shown in Figure 2.

The measured values for stem thickness classification were fitted to RRSB distribution. An average stem thickness can be calculated on the basis of this distribution (M 50 value, 50 weight \% of stems are thinner and 50 weight \% of stems are thicker). This information could then be used to estimate the actual stem content of the cut tobacco using the following two methods:

- Calculation on the basis of the existing stem thickness categories

- Calculation on the basis of an average stem thickness from the RRSB distribution
Figure 3 shows the calculated actual percentage of stems in the cut tobacco in relation to the "non-critical cutting width" for cut tobacco with a cutting width of $0.8 \mathrm{~mm}$ and a $24.2 \%$ stem content in the leaf.

In the case of a non-critical cutting width of $0.4 \mathrm{~mm}$ (half cutting width), a stem content of only approximately $16 \%$ was found in the cut tobacco. If we also take into consideration that not all stems are cut lengthways, as assumed for purposes of simplification, we should expect that the actual percentage of stems in the cut tobacco will be even lower. Against this background, the laboratory analysis values of (approximately $14 \%$ ) for semi-oriental tobacco seem realistic. Further we can assume that cut stems which are cut to half the cutting width are no longer identified as such in the cut tobacco, although this is clearly a matter of definition.

Conclusion: As a result of stem thickness, the percentage of stems contained in cut tobacco is lower than the percentage of stems contained in the leaf.

We can assume that approximately $50-80 \%$ of the stems become objectionable, or critical stems after cutting. The ability to remove these stem particles from the cut tobacco without degrading the long fibres is the objective of every cigarette manufacturer concerned with 


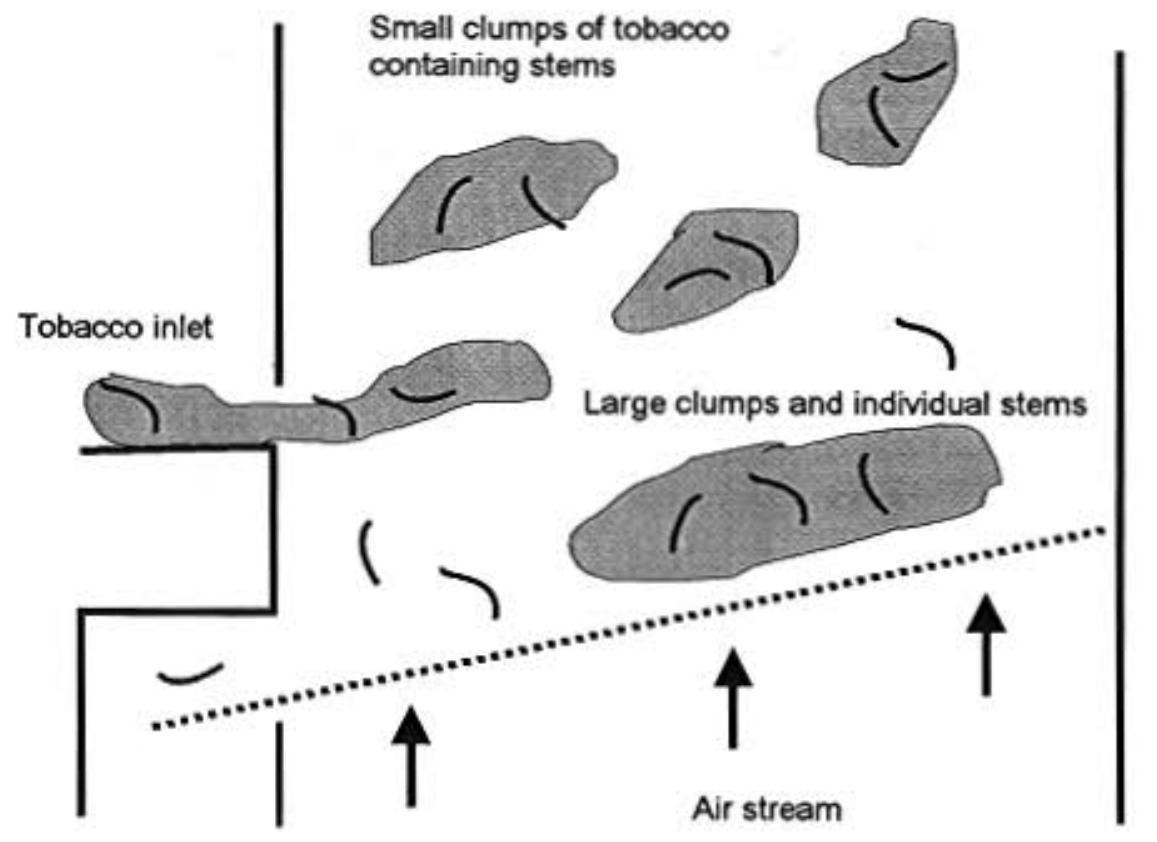

Figure 4.

Cut tobacco separation in a standard vertical separator.

high product quality. In the production of oriental cigarettes, particularly when using semi-oriental tobaccos, the reduction of the stem content of the cut tobacco is critical in maintaining high product quality. Here we must assume an objectionable stem content of $12-16 \%$. It is perhaps not surprising that recent years have seen ever more cigarette manufacturers looking for a machine able to remove stem particles from cut tobacco.

This request from the market prompted Hauni Maschinenbau AG, in its capacity as supplier of primary processing equipment to the cigarette industry, to give priority to the development of such a machine.

In initial trials horizontal air was used to separate cut tobacco. This process is used successfully for removing knockouts from CRS, however, results were negative for this application.
The separation of particles in an air stream is based on the principle that particles of different density and shape fall at different speeds. The process relies on the presence of individual particles which can be surrounded by the air stream without hindrance. In contrast to CRS, cut tobacco is not present as individual particles: its long fibres cause it to entwine heavily. The individual particles are therefore not surrounded by the air stream. When the cut tobacco is introduced to a horizontal transverse air stream, the tobacco forms clumps as shown in Figure 4. These flying clumps fall at a speed determined by their size and air permeability. Stem particles become trapped in these clumps. Turbulence in the air stream causes clumps to fall apart and form smaller clumps, or to join with other clumps to form larger ones. Even if stem particles are released from clumps which fall apart, or if stems fall off clumps, it is not possible to separate stems

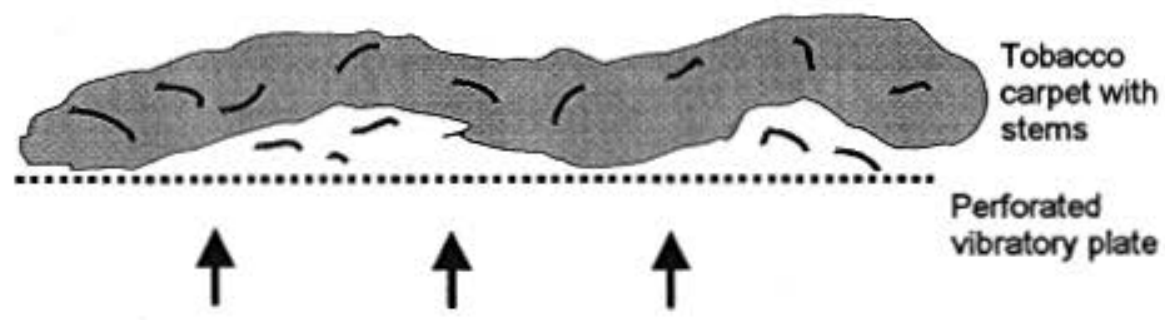

Air stream

Figure 5 .

Cut tobacco in a standard fluidized bed cooler. 
and cut tobacco in an air stream as large clumps of tobacco fall either faster than stem particles, or at the same speed. This type of separator separates large and small clumps of tobacco but can not be used to separate stems from cut tobacco.

The action of sieving cut tobacco on a vibratory conveyor separates stem particles and a large proportion of shorts. This action, however, subjects the tobacco to high mechanical stress which can cause degradation. The shorts would have to be separated from the stems in a second processing stage e.g. in a transverse air stream separator.

Thus mechanical energy is required to loosen stems from the tangled cut tobacco. However, the discharge and generation of shorts must be avoided.

A fluidized bed cooler provides a vibratory conveying motion and gentle tobacco handling. The tobacco is conveyed in a vibratory conveyor and is subjected to an air stream, applied at right-angles to the tobacco, which is able to separate the stems from the shorts. In the fluidized bed cooler the cut tobacco forms a carpet which hovers along the perforated plate in the form of a wave, as shown in Figure 5. The vibration and fluidization of the tobacco shake stems free of the carpet and causes them to fall on to the perforated plate. The underside of a tobacco carpet processed in this way does not, however, exhibit a concentration of stems. Stems are

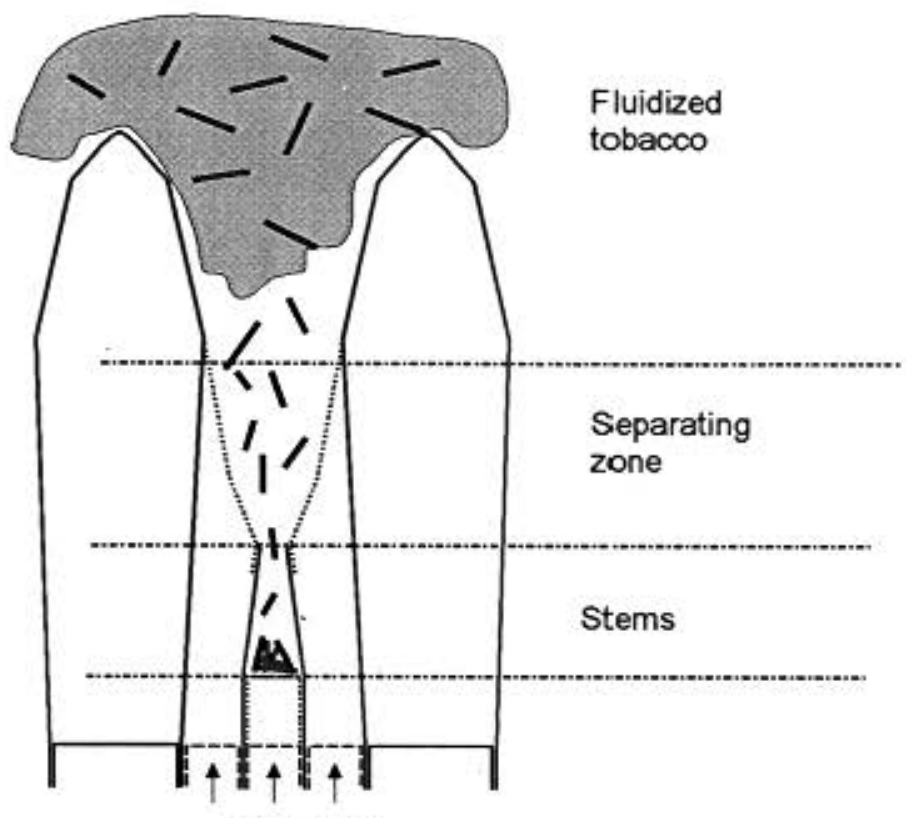

Air stream

Figure 6.

Cut tobacco separation in cut tobacco fluidized bed separator, Hauni Maschinenbau AG.

blown back into the carpet or are picked up by the carpet as it moves along the perforated plate.This process is thus unsuited to removing stem particles from cut tobacco.

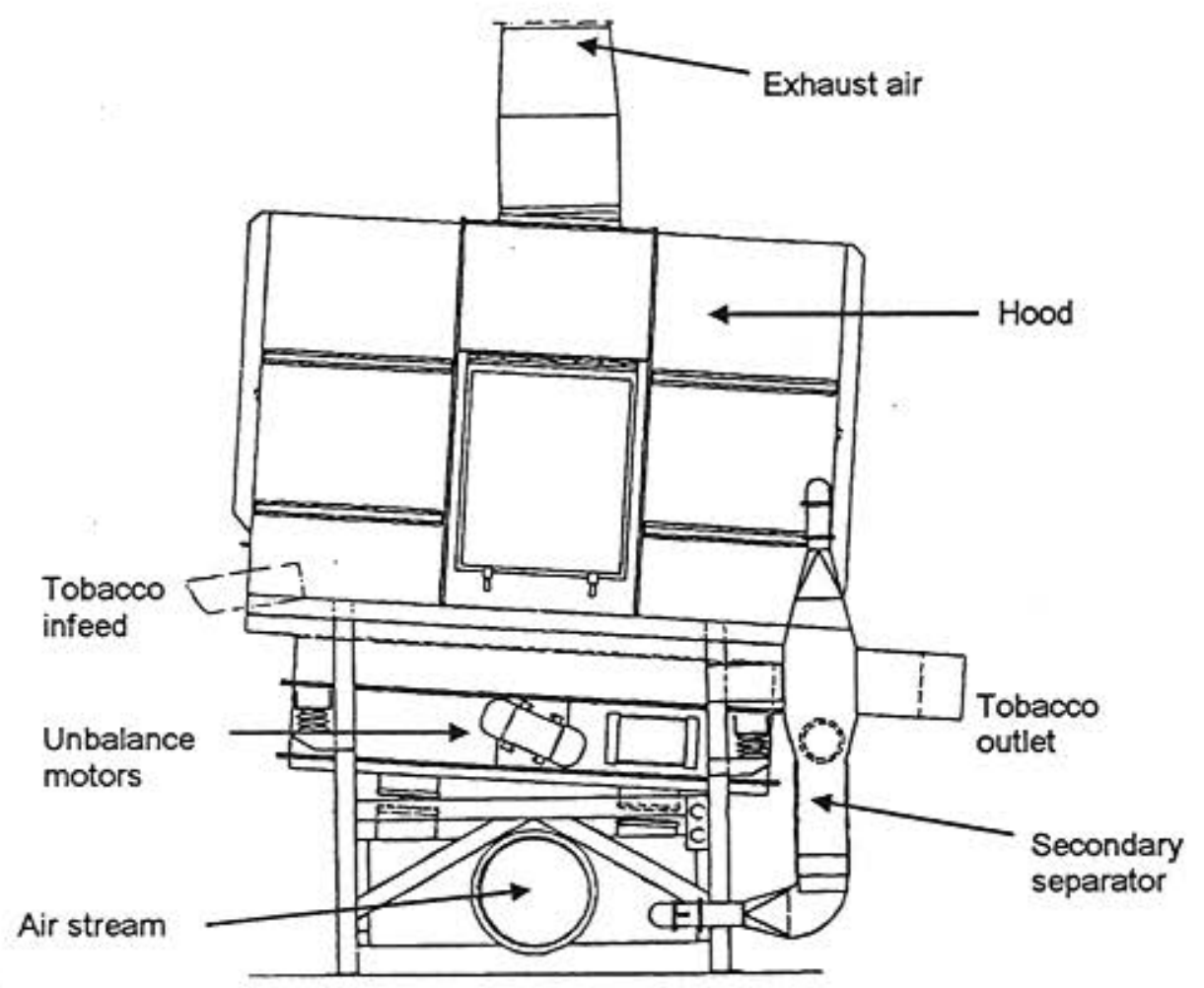

Figure 7.

Cut tobacco separator, Hauni Maschinenbau AG (pilot plant). 


\section{CONCLUSIONS}

In summary, the following conditions are required for separating stem particles from cut tobacco:

- Stem particles must be shaken out of the tangled structure of the cut tobacco

- Mechanical energy and time are required for this processing stage

- Shorts removed with the stems must be separated from the stems in an air stream

- Stems must be removed from the cut tobacco as soon as they are released from it to prevent them becoming re-entangled in the cut tobacco fibres

These factors formed the basis of a fluidized bed separator for cut tobacco based on an idea provided by Rothmans UK. The tobacco is fluidized in troughs vibrating lengthways. Figure 6 shows a section through these troughs. The vibratory movement of the tobacco causes stem particles to drop out of the tangled structure of the cut tobacco and fall into the troughs. A vertical air stream in the troughs separates the stems from any shorts present. The heavy stems fall into a gap on the lower side of the troughs and are thus reliably separated from the tobacco carpet. The stems are conveyed at the base of the gaps, away from the fluidized cut tobacco, and discharged. The tobacco carpet is discharged from the end of the troughs above the gap.

This separator for cut tobacco is also able to utilize the air required for fluidizing the tobacco for cooling e.g. downstream of a drier. An airlock is not required for separating the tobacco from the air, thus reducing degradation. A prototype with a throughput of $1000 \mathrm{~kg} / \mathrm{h}$ has been running for one year in a German cigarette factory. Machine efficiency is approx. $65 \%$ reduction of stems that do not pass thorough a mesh size of $3.15 \mathrm{~mm}$ in a sieve test.

The throughput of the separator is to be increased in a further development stage. Target throughput is 5000 $\mathrm{kg} / \mathrm{h}$. A smaller model, see Figure 7, is available in the Hauni Maschinenbau AG pilot plant in Hamburg Bergedorf for tests with customers' tobacco.

\author{
Authors'address \\ Hauni Maschinenbau $A G$ \\ Kampchaussee 8.32 \\ D.21033 Hamburg
}

